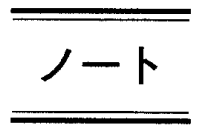

FCR による胸部の One Shot Dual Energy Subtraction について

\author{
京都大学結核胸部疾患研究所附属病院放射線部 \\ 浜川純一・田中龍蔵 \\ 京都大学医学部附属病院放射線部 \\ 米田和夫 \\ (論文受理１985年 2 月28日） \\ （最終論文受理１985年 7 月19日） \\ (Code No. 345, 423)
}

Key words : One shot dual energy subtraction, Computed radiography, Imaging plate and filter, Image processing.

\title{
ONE SHOT DUAL ENERGY SUBTRACTION OF THE CHEST USING FCR SYSTEM
}

\section{JUNICHI HAMAKAWA and RYUZO TANAKA}

Department of Radiology, Hospital of Chest Disease Research Institute, Kyoto University

\section{KAZUO YonedA}

Department of Radiology, Kyoto University School of Medicine

(Article received; Feb., 28, 1985)

\section{Summary}

One shot dual energy subtraction for chest using the FCR, IP (Imaging Plate) system that Fuji Photo Film CO., LTD. developed, was tested and the possibility of utilizing this method clinically was investigated.

Putting three IPs to the IP cassette, and then putting filter material of $\mathrm{Cu} 1 \mathrm{~mm}$ or $\mathrm{Sn} 0.3 \mathrm{~mm}$ between the first layer and second layer, we took a radiograph of the chest.

This method is, using the change of beam quality by absorption which is peculiar to each material, to get the energy subtraction image. Energy difference between them is about $20 \mathrm{keV}$ using the $\mathrm{Cu} 1 \mathrm{~mm}$ or $\mathrm{Sn} 0.3 \mathrm{~mm}$ filter.

Incident dose is increased because the radiation dose of the second layer is decreased by the absorption of the filter. However we can get a clinically significant subtraction image by image processing which uses the weighting factor to the subtraction. 
This method, compared with cassette changer method, has no motion artifact by time lag, phase of breath and phase of heartbeat, so it is suitable to be used for moving organs.

We cannot draw a conclusion from clinical evaluation of thoracic subtraction, because it is still in the experimental stage. However we expect that it will be one of the effective methods for diagnosing diffuse lung diseases.

\section{1.はじめに}

Computed tomography（CT）の開発にともない医用 画像の digital 化が進められると相まって画像処理技術 が長足の進歩を遂げ，その臨床的応用が盛んに抢こなわ れている.特に DR， DF ${ }^{1) \sim 4)}$ の普及と併せて SPR (scanned projection radiography ${ }^{5) 6}$ scannography 等 $の$ digital X線画像による subtraction 技術の研究がなさ れるとともに臨床面における有用性について報告されて (る4)7) 11).

われわれは先に富士写真フィルム株式会社で開発した imaging plate (以下 Ip と略す)を用いた Fuji computed radiography $(\mathrm{FCR})^{12) \sim 17)}$ による one shot dual energy subtractionを試み，今回は特に胸部領域における臨床 的応用の可能性について検討し，知見を得たので報告す る.

\section{2. 使用機 器}

$\begin{array}{ll}\text { X線装置 } & \text { ID }-150 \mathrm{G}_{2} \text { (島津製) } \\ \text { X線管 } & \text { サークレックス } 1 / 2 \mathrm{P} 13 \mathrm{C} \\ \text { 画像処理 } & \text { FCR system } \\ \text { Ip } & \text { Ms および ST } \\ \text { 測定器 } & \text { NERO X-ray analyzer } \\ & \text { Victoreen 社製 } \\ \text { ファントム } & \text { アクリル板 アクリル階段 } \\ & \quad \text { 肋骨 (dry bone) } \\ \text { フィルタ } & \mathrm{Cu} 1 \mathrm{~mm} \text { または Sn } 0.3 \mathrm{~mm} \\ \text { グリッド } & 12: 1 \text { (移動型) }\end{array}$

\section{3. 方法}

\subsection{Dual Energy Subtraction について}

Dual energy subtraction 法は組織のX線吸収係数の 差を利用するもので一般には同一部位に対して異なった エネルギー，すなわち高圧撮影と低圧撮影をそれぞれお こない各々の画像信号に適当な重み係数をかけて差分画 像を求めている。たとえばX線管電圧 $120 \mathrm{kV}$ と $60 \mathrm{kV} の$ 撮影をカセッテチェンジャ等を用いておこなう方法がと られている。
しかしこの方法はカセッテの交換時間，撮影条件 $(\mathrm{kV}$ mAs 值) の設定に時間がかかるため体動による差分画像 の画質が劣化する。特に胸部の場合は呼吸の位相合好や， 心拍の同期をとることが難しく motion artifact が発生 しやすく実用的でないものと考える。

\subsection{One shotによる dual energy subtraction 法}

One shotによる dual energy subtraction 法は Ziedses des plantes (1931) ${ }^{18\rangle}$ によりカセッテに感度の異なる 複数の増感紙と二枚のフィルムを用い，その間に銅フィ ル夕を入れ試みられていることが報告されている。

われわれのおこなった方法は Fig. 1 のごとくIp力セ ッテに 3 枚の Ip を入れ，その間に Cu $1 \mathrm{~mm}$ または $\mathrm{Sn}$ $0.3 \mathrm{~mm}$ のフィルタを插入する。被写体を透過したX線 は Ip 一層目で蓄積, 記録されるとともにフィルタを透過 して低エネルギー成分が濾過されたX線により Ip 二層 目に情報を与える。したがって Ip 一層目と二層目の差分 画像を求めることにより energy subtraction 像を得る という方法である。FCR 方式は screen film 方式に較べ,

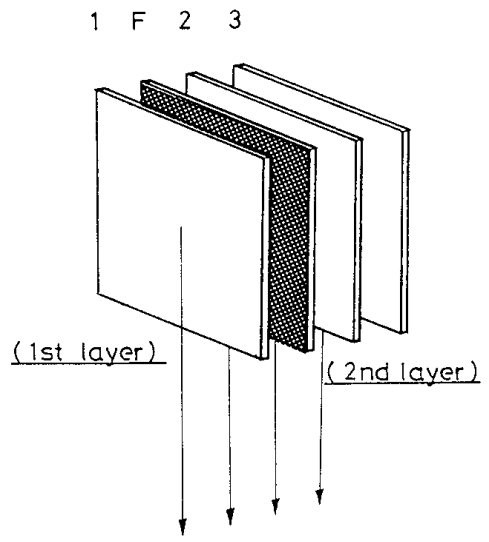

$1,2,3=I P$ $F=$ Filter

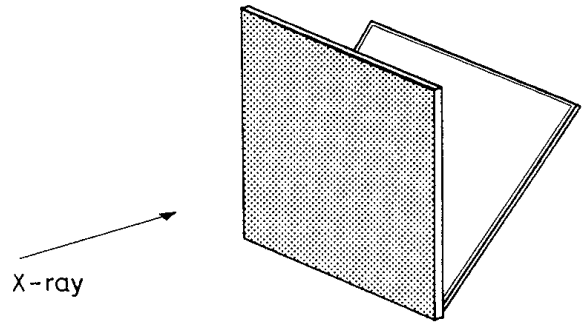

Fig. 1 Diagram arrangement of the imaging plate and filter. 
Ipのもつ特性としてX線強度に対する4桁にわたる広 いダイナミックレンジを有している。これにより入射 X 線量に合せた適当な画像信号が取り出されるので容易に サブトラクション処理がおこなわれ，フィルタを用いた one shot による dual energy subtraction 法が可能にな った.

しかし,フィル夕透過後 Ip 二層目に扔いてX線量が極 度に減少 (約 $1 / 8$ 程度)するため入力信号も減少し画像処 理において雑音成分が強調される。この点を改善するた めに二層目には Ip (Ms) を二枚重叔合せて加算処理をお こないランダムな雑音成分を減少させている。

\section{4. 結果}

\section{1 ファントム実験による実効電圧の測定結果}

$\mathrm{X}$ 線撮影条件は X線管電圧 $100 \mathrm{kV}$ 45 75 mAs FPD $150 \mathrm{~cm}$ で格子比 $12 ： 1$ の移動型グリッドを附属した R ブッキー撮影台を使用している．Fig. 2 はアクリルファ ントム $8 \mathrm{~cm}$ 用い実際の撮影条件により NERO X-ray analyzer を用いて実効電圧を半価層より求めた測定配 置図である。

$\mathrm{Ip}$ 一層目とフィルタ $\mathrm{Cu} 1 \mathrm{~mm}$ または $\mathrm{Sn} 0.3 \mathrm{~mm}$ 透過した二層目に抢ける実効電圧を測定值より求めたと ころ夫々 $47 \mathrm{keV}$ と $65 \mathrm{keV}$ で約 $18 \mathrm{keV}$ のエネルギー差 があるものと推定される。一方，カ七ッテチエンジャ法 を用いた撮影条件（X線管電圧 $60 \mathrm{kV}$ と $120 \mathrm{kV}$ )に占り 比較検討したが夫々 $36 \mathrm{keV}$ と $57 \mathrm{keV}$ となり差は 21 $\mathrm{keV}$ でエネルギー差に扔いて本法と余り変りないもの と考える (Fig. 3).

また Kulen Kampff の実験式を用いて $100 \mathrm{kV} の \mathrm{X}$ 線 スペクトルを計算により求めるとともに $\mathrm{Al} 2 \mathrm{~mm}$ およ び Cu $1 \mathrm{~mm}$ または Sn $0.3 \mathrm{~mm}$ のフィル夕透過後のスペ クトルを比較したが, Cu $1 \mathrm{~mm}$ は $40 \mathrm{keV}$ から $100 \mathrm{keV}$ の間において Sn $0.3 \mathrm{~mm}$ と合致していることが推定さ れる(Fig.4)。したがって重ね合せによる artifact を考 慮すればフィルタは薄い方が良く, 最近では Sn $0.3 \mathrm{~mm}$ を主として使用している。

\subsection{Bone Subtractionについて}

胸部X線写真の肋骨陰影を消去する bone subtraction 画像を得るには出力信号の対数変換に加えて信号 の重みづけが必要で, Ipの一層目 (low energy image) と二層目 (high energy image) とに夫々異なった係数 (weighting factor) をかけ画像処理をする重みづけ差分 法がとられている，Fig. 5 は $\mathrm{Cu} 1 \mathrm{~mm}$ また $\mathrm{Sn} 0.3$ $\mathrm{mm}$ を用いた場合の重み係数值でアクリルファントム

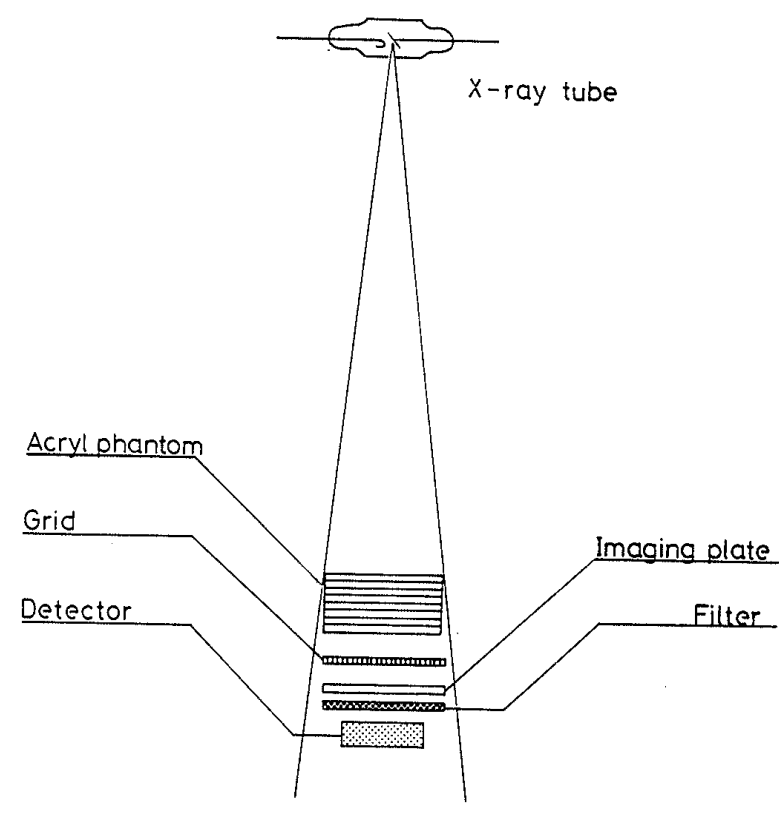

Fig. 2 Exposure geometry used for measurements of HVL.

Cassette changer method
$60 \mathrm{kVP}$ ?

$36 \mathrm{KeV}$

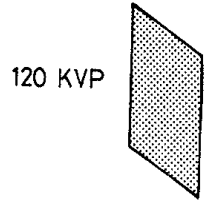

$57 \mathrm{KeV}$
Ip filter method
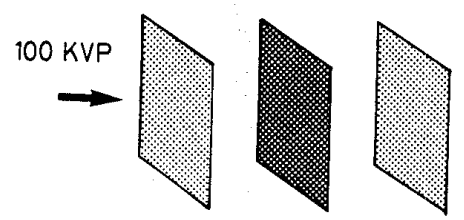

$47 \mathrm{KeV} \quad \mathrm{Sn}$ or $\mathrm{Cu} \quad 65 \mathrm{KeV}$

Fig. 3 Comparison of photon energy (KeV) using cassette changer method and lp filter method.

と助骨消去の度合との関係を表わしたもので Fig. 6 は その害験に用いたファントムの写真である.

Fig. 7 は前述の方法によって実際 bone subtraction をした同じ患者の胸部 $\mathrm{X}$ 線写真である。通常のX線写真 aを対照として重み係数 2.0 扔よび1.7と変化させた subtraction 像 b， c である. 3 枚の写真を比較すると肋 骨が消元る度合は係数值 2.0 亿較べ 1.7 顕著で Fig. 5 のファントム実験の結果とほぼ一致している. 重み係数 


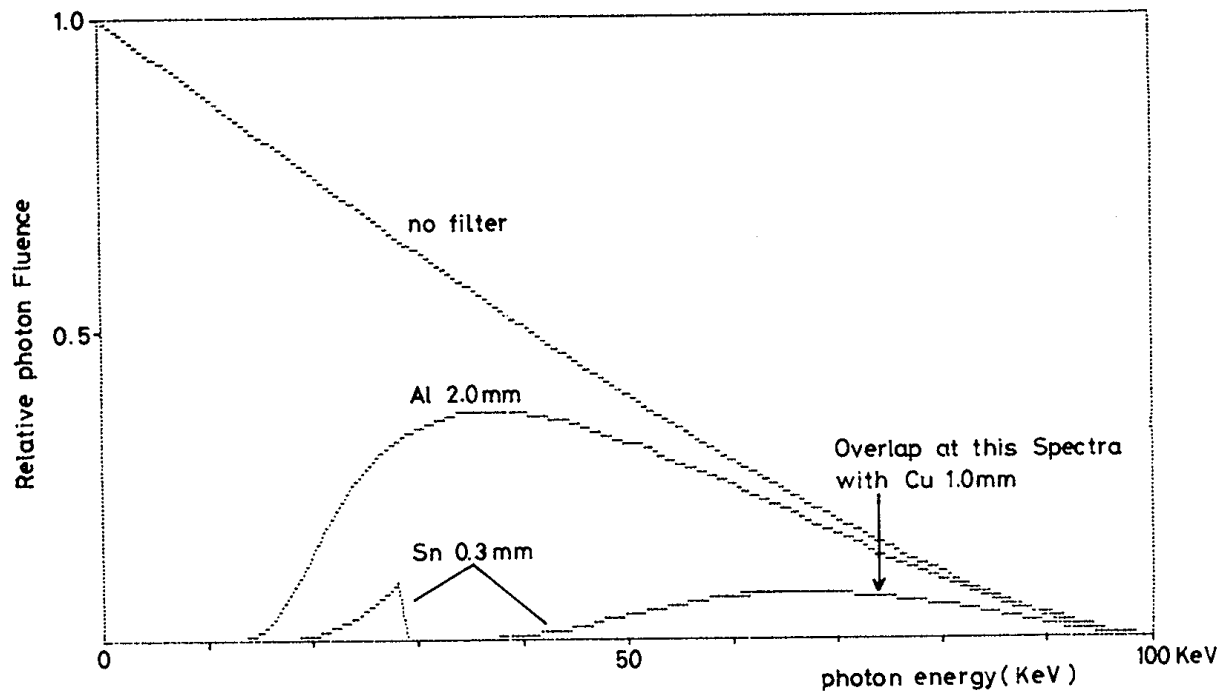

Fig. 4 Transmitted spectra through $\mathrm{Cu} 1 \mathrm{~mm}$ and $\mathrm{Sn} 0.3 \mathrm{~mm}$ at $100 \mathrm{kV}$ using Kulen Kampff's experimental formula.

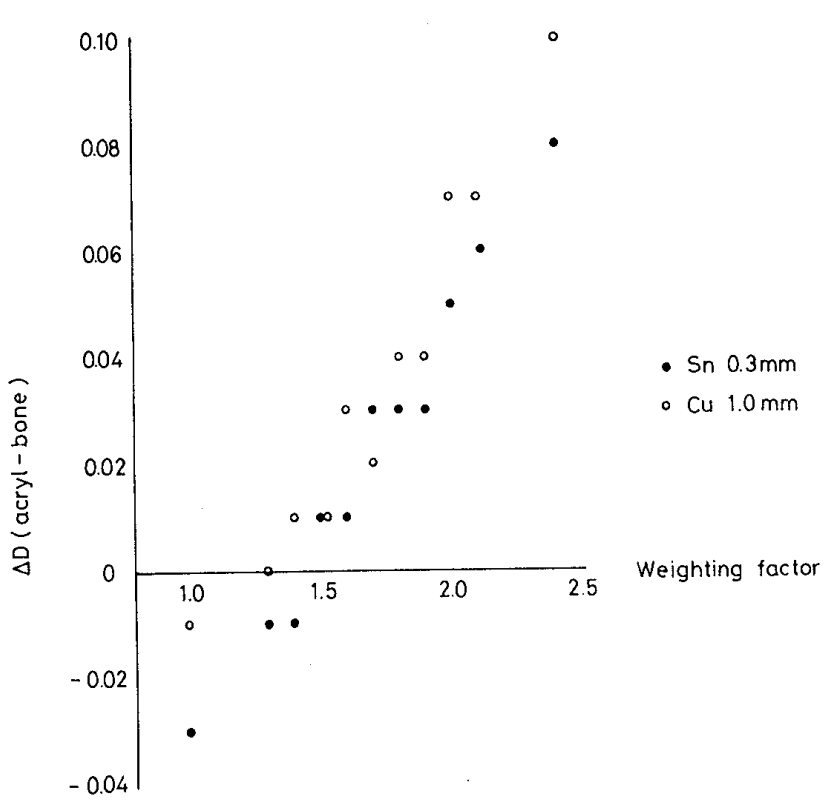

Fig. 5 Relation between weighting factor and $\mathrm{AD}$ (acryl-bone) using $\mathrm{Cu} 10 \mathrm{~mm}$ and $\mathrm{Sn}$ $0.3 \mathrm{~mm}$.

を低くすれば助骨消去の度合と併せて全体のコントラス トが低下し, 肺内の微細構造, 特に末梢血管陰影の現出 能が低下する傾向になるが，同じ重み係数であっても階 調処理条件と周波数処理条件を変化することによって診 断目的に対応した微細陰影の描出が可能であるものと考 えられる.d は重み係数值を1.7として周波数処理条件の みを変化させ, 低周波部分を強調した一例である. 全体

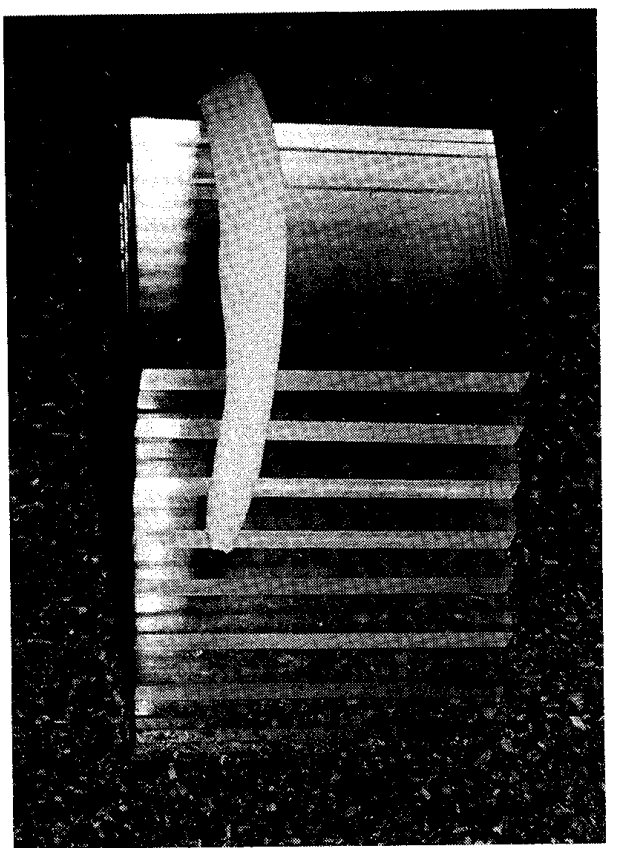

Fig. 6 Experimental arrangement of the acryl step and dry bone. 
FCR による胸部の One Shot Dual Energy Subtraction について（浜川・田中・米田）
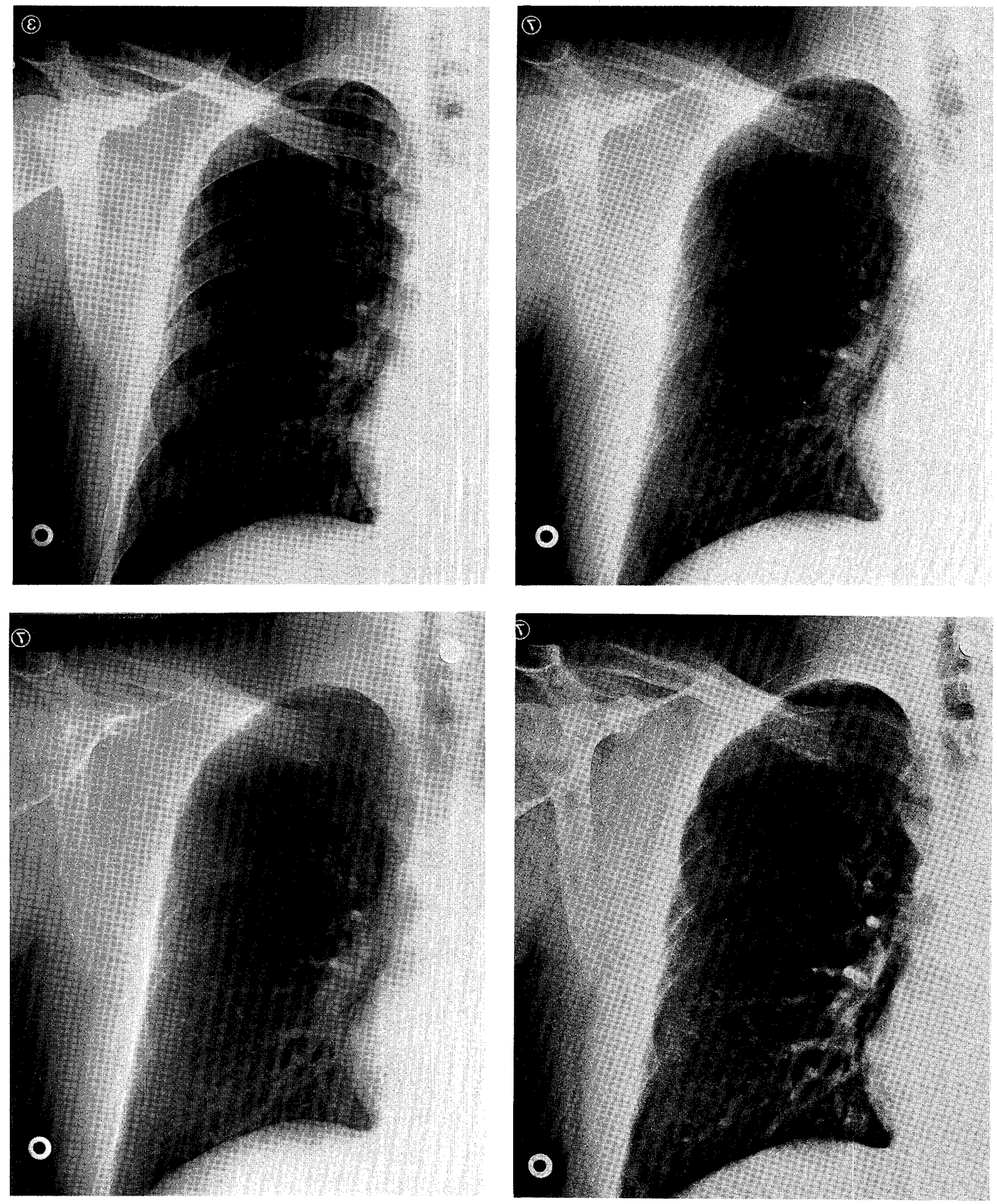

Fig. 7 Comparison of chest dual-energy subtraction radiographs using various weighting factors.

a. Conventional radiography

b. W.F. 2.0

c. W.F. 1.7

d. Bone subtraction image enhanced low frequency component using W.F. 1.7. 


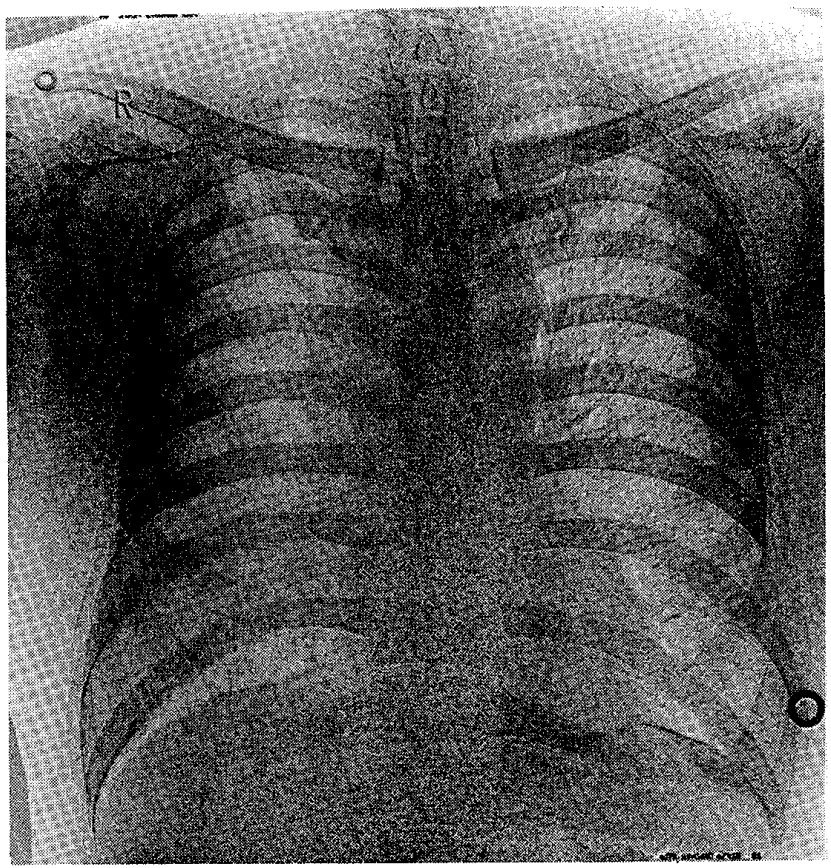

Fig. 8 Tissue subtraction radiography.

ることがわかった. Fig. 8 は tissue subtractionをした 一例である。

\section{5. 考察}

胸部の energy subtractionにおける画像処理条件を 標準化し臨床的に広く応用するとともに各症例に対応し た適切な画像処理条件を選択することにより，肺実質お よび血管，気管支陰影ならびに病巣等が選択的に強調さ れ，臨床上有意義な subtraction 像が得られるものと考 える。

なお，本法における胸部の bone subtraction 像では骨 のイメージが弱く残り，特に鎖骨，第一，二胁骨の消去 は難しい，骨を完全に消去することはdual energy 法の みでは期待できないが，ほぼ当初の目的が達せられたも のと考える。

\section{6. 結 論}

われわれがおこなったIpとフィルタによる one shot dual energy subtraction 法はカセッテチェンジャ法に 較べると時間差による動きの歪みがなく肺，心臓等の動 態蔵器を対象とする場合には適していると考える。

しかし，本法はフィルタ物質固有の吸収によるエネル ギー差を利用する方法であるために入射 X線量が多くな る、これを改善するために活像処理条件，方法の選択 ならびにX線量子の利用効率を上げるため一層目と二層 目のIp 感度の最適化および，それにともなう技術的開発
等，今後の研究課題である.

一方，本法における胸部の subtraction 像についての 臨床的評価については未だ実験途上で結論づけられない 現状であるが，最近，胸部疾患の関心事である濔漫性疾 患，特に中，下肺野に病巣が散在する DPB，IIP 等の診 断に有効な手段として活かされるものと考える.

\section{謝辞}

稿を終るにあたり FCRの使用に御配慮賜わった京都大学 医学部附属病院放射線部長 鳥塚莞爾教授, 中野善久講師な らびに画像診断について終始御指導御助言頂いた放射線部 副部長 伊藤春海助教授に深甚の謝意を表します.また実効電 圧の測定に関し御指導衔協力頂いた京都医療技術専門学校 山田勝彦，藤本信久先生に厚く御礼申し上げます。

本論文の要旨は第41回日本放射線技術学会総会で発表した。

\section{参考文献}

1）片山仁，幾瀬純一：Digital Radiography，（世界の 動向)，画像診断，2(3)，52-54 (1982).

2）赤塚孝雄：ディジタル画像処理技術の進歩と画像診 断，日本臨床，41(7)，4-14，(1883).

3）飯沼武：ディジタルX線映像法，日本臨床，41(7), 15-19, (1983).

4）大野英丸，小野研一：Digital Fluorography，日本 臨床，41(7)，20-26，(1983).

5）阿部博幸，他：Scanned projection Radiography, 映像情報，9，（1982）。

6) 阿部博幸, William R. Brody: Projection Radiography system, 日本臨床，41(7)，36-46, (1983).

7) Theodore L. ldouk, et al.: Real-Time Digital K-Edge Subtraction Fluoroscopy, Investigative Radiology, 14(4), 270-278, (1979).

8) William R. Brody, et al.: Dual-Erergy projection Radiography, AJR 137, 201-205, (1981).

9）松原一仁，佐久間貞行他：Computed Rediography の臨床応用と問題点, 日本臨床，41(7)，124-133, (1983).

10）松尾啓志，堀場勇夫，他：Computed Radiography を用いたDual Energy 法の検討，放射線映像研究， 13(1), 21-27, (1983).

11）堀場勇夫：時間差分法とエネルギー差分法の問題, 日本臨床，41(7)，66-74，(1983)。

12）高野正雄：新しいComputed Radiography, 画像診 
断, 2(3), 202-207, (1982).

13）高野正雄：輝尽性蛍光体を使った新しい Computed Radiography, 日本臨床，41(7)，27-35，(1983)。

14) M. Sonoda, M. Takano, et al. : computed Radiography utilizing Scanning Laser Simulated Laminesence, Radiology 148(3), 833-838, (1983).

15）蜂屋順一, 他：輝尽性蛍光体を用いたコンピューテ ッド，ラジオグラフィー，医学のあゆみ，127(14),
1199-1206, (1983).

16）蜂屋順一, 他：胸部疾患の診断とデジタルラジオグ ラフィー，医学のあゆみ，127(14)，1292-1298， (1983).

17）秋貞雅祥 (監修)：ディジタルラジオグラフィー・ラ イフサイエンス センター，(1982).

18) B.G.Ziedses Des Plantes: Subtraktion, Georg Thieme Verlag • Stuttgart (1961).

\title{
追 記
}

\section{1 ショットエネルギーサブトラクションの数学的説明}

\author{
富士メディカルシステム侏 荒 井徹
}

1 ショットエネルギーサブトラクションは, 連続エネルギースペクトルによる信号エネルギーを考えなければ, 意味 がない.ここでは, 下図のような吸収係数の異なる 2 種類の物質で構成される被写体を考える.ただし，散乱線の影響 はないものと仮定する。

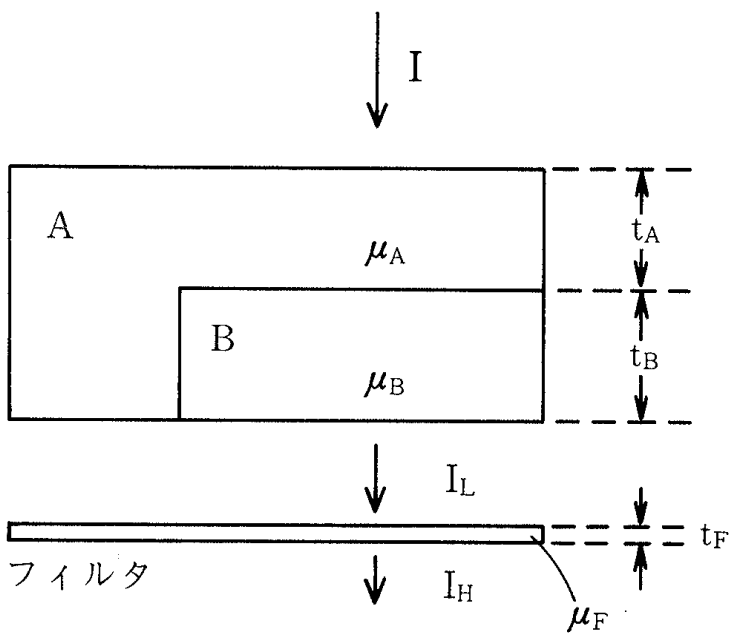

$$
\begin{aligned}
& \mathrm{I}=\int \mathrm{f}(\mathrm{E}) \mathrm{dE} \\
& \mathrm{f}(\mathrm{E}): \text { 連続エネルギースペクトル } \\
& \mathrm{E}: \text { photon エネルギー }
\end{aligned}
$$

$$
I_{L}=\int f(E) \exp \left\{-\mu_{A}(E) t_{A}-\mu_{B}(E) t_{B}\right\} d E
$$$$
I_{H}=\int f(E) \exp \left\{-\mu_{F}(E) t_{F}-\mu_{A}(E) t_{A}-\mu_{B}(E) t_{B}\right\} d E
$$

ここで $\mathrm{g}(\mathrm{E})=\mathrm{f}(\mathrm{E}) \exp \left\{-\mu_{\mathrm{F}}(\mathrm{E}) \mathrm{t}_{\mathrm{F}}\right\}$ とおく.

1 ショットエネルギーサブトラクションで, イメージングプレート上に記録, 読出された後の信号は, $\mathrm{I}_{\mathrm{L}}$ と $\mathrm{I}_{\mathrm{H}}$ を対数 処理した值であるから，エネルギーサブトラクション処理をすることは下記の関数 $\mathrm{F}\left(\mathrm{t}_{\mathrm{A}}, \mathrm{t}_{\mathrm{B}}\right)$ を作ることに対応する.
$\mathrm{A}, \mathrm{B}$ ：吸収係数の異なる物質

I : 入射X線のエネルギー

$\mathrm{I}_{\mathrm{L}}$ : 被写体透過後のエネルギー

$\mathrm{I}_{\mathrm{H}}:$ フィルタ透過後》

$\mu_{\mathrm{A}}, \mu_{\mathrm{B}}, \mu_{\mathrm{F}}$ : 各物質のX線に対する吸収係数

$t_{A}, t_{B}, t_{F}:$ 各物質の厚み 